Title:

\title{
Comorbidities contribute substantially to the severity of common
}

\section{multiple sclerosis symptoms}

Authors:

Lara Marie Pangan Lo ${ }^{1}$, Bruce V. Taylor ${ }^{1}$, Tania Winzenberg ${ }^{1}$, Andrew J. Palmer ${ }^{1,2}$, Leigh Blizzard ${ }^{1}$, Ingrid van der Mei ${ }^{1, *}$

\section{Affiliation:}

${ }^{1}$ Menzies Institute for Medical Research, University of Tasmania, Hobart, TAS 7000, Australia

${ }^{2}$ Centre for Health Policy School of Population and Global Health, The University of Melbourne, Level 4, 207 Bouverie Street, Melbourne, VIC, 3053, Australia

\section{*Corresponding Author:}

A/Prof Ingrid van der Mei

Menzies Institute for Medical Research, University of Tasmania, 17 Liverpool Street, Hobart, TAS 7000, Australia.

Phone: (61) 362267710 and Fax: (61) 362267704

Email: Ingrid.vanderMei@utas.edu.au

Keywords: multiple sclerosis, prevalence, comorbidity, symptoms, musculoskeletal disorder, mental health disorder 


\section{Abstract}

Background: More research is needed to understand the contribution of comorbidities to MS symptomatology.

Objectives: To examine the dose-response relationship between the number of comorbidities and severity of MS symptoms and to assess the relative contribution of comorbidity groups and individual comorbidities to the severity of each symptom.

Methods: We surveyed 1,223 participants of the Australian MS Longitudinal Study for the presence of 30 comorbidities and the severity of 13 MS symptoms ( $0-10$ scale). The associations between comorbidities and symptoms were assessed using negative binomial regression. The relative contributions of comorbidities to the severity of symptoms were assessed using general dominance analysis.

Results: Higher number of comorbidities was most strongly associated with a higher severity of pain and feelings of anxiety and depression (ratios of means $\geq 0.12$ per comorbidity increase). Comorbidities explained between $3.7 \%$ (spasticity) and $22.0 \%$ (feelings of anxiety) of the total variance of symptom severity. Mental health and musculoskeletal disorders contributed most strongly to the severity of the most common symptoms in MS.

Conclusions: Our findings support that early recognition and optimal management of comorbidities, particularly of mental health and musculoskeletal disorders, could have a positive impact on the severity of symptoms of people with MS. 


\section{Introduction}

Multiple sclerosis (MS) affects more than 2.5 million people worldwide and is considered one of the most common disabling neurological disorders. ${ }^{1}$ The symptomatology ranges from physical symptoms including vision loss, spasticity, bladder and bowel dysfunction, walking and balance problems, fatigue and pain to psychiatric issues like cognitive impairments, depression and anxiety. ${ }^{2,3}$ Previous research showed the strong impact these symptoms have on the quality of life of people with MS. ${ }^{4}$ However, most of these symptoms are not specific to MS and could be related to other medical conditions. ${ }^{5}$ The majority of people with MS (PwMS) have comorbidities, ${ }^{6,7}$ and understanding how comorbidities influence the symptomatology of MS could assist in guiding the management of symptoms in MS.

Comorbidities make a substantial contribution to reduced quality of life and general well-being of PwMS. ${ }^{8}$ However, our understanding of the extent to which comorbidities influence the severity of different symptoms in MS is limited..$^{9-11}$ In a cross-sectional study of 339 PwMS, the severity of common symptoms such as fatigue, balance problems and weakness was significantly higher in PwMS who had comorbidities such as depression, anxiety, migraine and coronary artery diseases compared to those without these comorbidities. ${ }^{9}$ In two longitudinal studies assessing the relationship between comorbidities and a single symptom (i.e. pain in one study ${ }^{10}$ and fatigue in the other ${ }^{11}$ ), the presence of comorbidities was associated with higher risk of experiencing these symptoms worsening over time. ${ }^{10,11}$ As these studies included a limited number of symptoms and/or comorbidities, they were unable to assess the cumulative impact of multiple comorbidities on the severity of symptoms or assess which comorbidities had the largest influence on each symptom. This is an important evidence gap.

Therefore, with data available from the Australian MS Longitudinal Study (AMSLS) on 30 comorbidities and 13 most common symptoms in MS, the goals of this study were to: 1) 
examine the dose-response relationship between the number of comorbidities and severity of each symptom, and 2) assess the relative contribution of comorbidity groups and individual comorbidities to the severity of each symptom.

\section{Methodology}

\section{Study population}

The AMSLS is a national sample of around 3,000 adult Australian volunteers with MS, ${ }^{12}$ of whom approximately $96 \%$ were diagnosed by a neurologist with definite MS using the McDonald criteria. ${ }^{13}$ It is an ongoing survey-based research project supported by MS societies in all Australian states and territories. Ethical approval for the study was initially given by the Australian Capital Territory Health Human Research Ethics Committee (HREC) and then by the Tasmanian Health and Medical HREC when the study centre was relocated to Tasmania in 2014. All participants provided informed consent.

Data used for this study came from two surveys. To assess comorbidities, we used the 2016 Lifestyle and Environment Survey ((August-October 2016); 3102 survey invitations sent and a total of $1,518(49 \% ; 1,067$ online and 451 paper) responded). To assess the severity of common symptoms in MS, we used the 2016 Medication and Disease Course Survey ((November 2016-March 2017); 3,098 survey invitations sent and a total of 1,699 $(56 \% ; 1,282$ online and 417 paper) responded). Those who completed both surveys $(\mathrm{N}=1,223)$ were included in the analysis.

\section{Measurements}

\section{Comorbidities}

The participants were asked "Do you have or have you had this condition?" (Yes/No) for each of the 30 most frequently reported comorbidities in MS. ${ }^{6,14,15}$ If yes, the participant was coded 
as having that comorbidity and we subsequently asked: "Was it diagnosed by a doctor?" (Yes/No/Don't know). If yes, the participant was coded as having that doctor-diagnosed comorbidity. The "Don't know" group was combined with the "No" group. The total comorbidities (i.e. any comorbidity the patient reported having) and doctor-diagnosed comorbidities (i.e. any comorbidity the patient reported as diagnosed by a doctor) were counted. The comorbidities were grouped according to the 263 blocks (disease categories) in the International Classification of Diseases $-10^{\text {th }}$ revision (ICD-10) structure. Due to power considerations, we excluded comorbidities reported by less than 10 participants which excluded Parkinson's disease and schizophrenia. The complete list of the 28 included individual comorbidities and the comorbidity groups to which they belong are shown in Figure 1 and Table 3, respectively.

\section{$\underline{\text { Symptoms severity measures }}$}

The severity of the 13 most common symptoms was assessed using the Multiple Sclerosis Symptom Scores (MSSymS) asking the participants to rate their average symptoms severity in the last four weeks compared to before they developed MS. ${ }^{16}$ MSSymS is a validated singleitem numeric rating scale of 0 to 10 , wherein 0 corresponds to "having no (symptom) compared to before developing $M S$ " and 10 equates to "worst possible (symptom), preventing many daily activities". ${ }^{16}$ The complete list of symptoms is listed in Figure 1.

\section{Other measures}

MS duration was calculated by subtracting years since MS symptom onset or years since MS diagnosis from survey date. Body mass index (BMI) was calculated by dividing self-reported weight (in kilograms) by height ${ }^{2}$ (in centimetres). Disability was assessed using the PatientDetermined Disease Steps Scale (PDDS), scored from 0 (no disability and only mild symptoms) to 8 (bedridden)) and a validated patient-reported instrument which has been 
strongly correlated with the Expanded Disability Status Scale (EDSS, r=0.78). ${ }^{17}, 18$ Data on sex, MS onset-type (i.e. relapse-onset and progressive-onset), disease modifying therapy status and education attainment were also obtained from the 2016 Medication and Disease Course Survey.

\section{Statistical analysis}

We used analysis of variance or $\chi^{2}$ tests to compare the differences between the PwMS who were included and not included in the analysis. Associations between the number of comorbidities and the severity of common symptoms in MS was evaluated using negative binomial regression. A dose-response was assessed using a test for trend. Potential confounders were identified by using causal diagrams and by examining whether the coefficient of each outcome (i.e. symptoms) variable was altered by more than $10 \%$ when a covariate (i.e. age, sex, MS duration, MS onset-type (relapse-onset vs. progressive-onset) and education level) was added to the model. ${ }^{19,20}$

We used linear regression with transformation to calculate the total variance $\left(\mathrm{R}^{2}\right)$ explained by the predictors (i.e. comorbidities) on each symptom severity variable. We applied general dominance analysis (using the domin add-on module in Stata), ${ }^{21}$ as proposed by Azen and Budescu, ${ }^{22}$ to determine the relative contribution of each comorbidity group (categorized according to ICD-10) to the total variance $\left(\mathrm{R}^{2}\right)$ of the severity of each symptom. In the groups with the highest contribution per symptom, the contribution of individual comorbidities belonging to that group was also determined. General dominance analysis provides an intuitive measure of predictor importance in two ways: 1) it uses the change in model fit (i.e., $\mathrm{R}^{2}$ ) to determine the contribution of each predictor and 2) it compares predictor contributions across all possible subset models from a given set of predictors. ${ }^{22,23}$ Results were presented as general dominance weights, standardized to be out of $100 \%$, to provide a ranking and weighting for each predictor in the model..$^{22}$ To examine whether the results differed for comorbidities that were reported to be doctor-diagnosed, we conducted a sensitivity analysis by limiting our 
analysis to doctor-diagnosed comorbidities. The significance level was set at $\mathrm{p}<0.05$ (twotailed). All analyses were performed using STATA/IC for Windows (version 15.0; StataCorp LP, College Station, Texas, USA).

\section{Results}

\section{Participant characteristics}

The mean age of the total cohort was 56.1 and $78.7 \%$ of included participants were female (Table 1). The average MS duration since symptom onset was 20.5 years, $87.8 \%$ had relapseonset MS, $62.1 \%$ were currently taking disease modifying therapy and $36.5 \%$ had university degree or higher. More than half of the participants were either overweight $(32 \%)$ or obese $(26 \%)$ (as defined by BMI $\geq 25$ ), and almost half of the participants had no to mild level of disability as defined by PDDS $<3(47.6 \%)$.

Non-response bias analyses comparing participants who were included with those who were not showed that those who were included were slightly older $(+1.34$ years; $p<0.01)$ and had a slightly longer MS duration ( +0.76 year; $p=0.02)$, but there were no significant differences in sex $(79 \%$ vs $76 \% ; p=0.72)$ and education attainment $(37 \%$ respondents have university bachelor's or postgraduate degree vs $34 \% ; p=0.18$ ).

\section{Prevalence of comorbidities}

The most prevalent comorbidities were depression (42\%), anxiety (39\%), allergies (37\%), hypertension (30\%), migraine (28\%), high cholesterol $(24 \%)$, osteoarthritis $(23 \%)$, eye diseases (15\%), cancer (14\%), anaemia (13\%) and osteoporosis (13\%) (Figure 1). 
For PwMS without comorbidity, the mean symptom severity ranged from 1.6 (vision problems) to 4.2 (difficulty with balance) (Figure 2). For those with 5 or more comorbidities, mean symptom severity ranged from 2.9 (vision problems) to 5.8 (fatigue). After adjustment for confounders, the association between the number of comorbidities and symptom severity was strongest for feelings of anxiety, feelings of depression and pain. Significant associations were observed for 2 or more comorbidities and the mean severity of these symptoms was on average 1.12 times to 1.13 greater for each additional comorbidity (Table 2) (Supplementary Table 1 shows unadjusted analyses). Significant associations were also observed for the other symptoms, but only for those with a higher number of comorbidities (i.e. 3 or more for sensory symptoms, 4 or more for fatigue, 5 or more for other symptoms) and effect sizes were lower with adjusted average ratios of means per comorbidity ranging from 1.02 to 1.08 (Table 2).

\section{Relative contribution of comorbidity groups on the severity of common symptoms in MS}

The comorbidities together accounted for $3.7 \%$ (spasticity) to $22.0 \%$ (anxiety symptoms) of the variance for symptoms severity (Table 3). General dominance analysis showed that mental health disorders (i.e. a diagnosis of depression or anxiety) had the largest relative contribution to the severity of symptoms such as feeling of anxiety (weighting=87\%), feelings of depression (85\%), fatigue (42\%), cognitive symptoms (66\%), sensory symptoms $(30 \%)$ and sexual dysfunction (35\%) and made the second greatest contribution (>20\%) to all other symptoms except bladder problems, walking difficulty and difficulty with balance. Musculoskeletal disorders had the largest relative contribution to the severity of the following symptoms: pain (30\%), walking difficulties (41\%), balance (35\%), bladder (33\%) and bowel $(34 \%)$ problems and spasticity (45\%). As would be expected, eye diseases (31\%) had the largest relative contribution to vision problems of PwMS.

Relative contribution of individual comorbidities on the severity of common symptoms in MS 
In the two comorbidity groups that had the largest contribution on the severity of common symptoms in MS (i.e. mental health disorders and musculoskeletal disorders), a diagnosis of depression had the largest relative contribution ( $28 \%$ or more) to feelings of depression, pain, fatigue, cognitive and sensory problems and sexual dysfunction and osteoporosis had the largest relative contribution ( $42 \%$ or more) to walking difficulties, balance, bladder and bowel problems and spasticity. A diagnosis of anxiety and eye diseases had the largest contribution to feelings of anxiety and vision problems, respectively (Table 4).

\section{Sensitivity analyses}

When we restricted our analyses to doctor-diagnosed comorbidities, we found similar associations between the number of comorbidities and the severity of common MS symptoms (Supplementary Figure 1 and Supplementary Tables 2 and 3). Similar patterns were also observed for the relative contribution of comorbidity groups and individual comorbidities to most MS symptoms except for pain (Supplementary Tables 4 and 5). For pain, mental health disorders $(27 \%)$ rather than musculoskeletal disorders had the largest contribution.

\section{Discussion}

To the best of our knowledge, our study is the first to examine the relative contribution of a wide range of comorbidity groups on the severity of the most common symptoms in MS in order to identify which comorbidity groups and individual comorbidities had the biggest impact. In this large representative cohort of Australians with established MS, higher number of comorbidities was strongly associated with the severity of all MS symptoms, with the strongest associations being for symptoms of feelings of anxiety, feelings of depression and pain. This suggests that the severity of common MS symptoms could be heavily impacted by a higher comorbidity load of PwMS. Among all the comorbidity groups evaluated in this study, 
mental health and musculoskeletal comorbidities contributed most strongly to the severity of most MS symptoms, implying that an early detection of these comorbidities may be a viable strategy to substantially reduced symptoms severity in PwMS. Overall, our findings support the premise that early screening, optimal management and prevention of comorbidities, particularly of mental health and musculoskeletal disorders, could have a positive prognosis on the severity of symptom of PwMS.

Comorbidities were prevalent, with $\sim 91 \%$ having at least one comorbidity and $\sim 27 \%$ having five or more comorbidities, which aligns with literature. ${ }^{6,24}$ The total number of comorbidities seems to have the biggest potential to impact on feelings of anxiety, feelings of depression and pain because the number of comorbidities was most strongly associated with these three symptoms, with the mean severity being significantly higher for those with two or more comorbidities compared to those without comorbidities. The effect sizes were less strong for the other symptoms and frequently only significant effects were observed when comparing those with higher numbers of comorbidities to those without comorbidities (i.e. 3 or more for sensory symptoms, 4 or more for fatigue, 5 or more for vision problems, cognitive symptoms, sexual dysfunction, spasticity, bowel problems, walking difficulty), suggesting that these symptoms are predominantly impacted when people have a very high comorbidity load.

Mental health disorders and musculoskeletal disorders had the largest relative contributions to the severity of common symptoms in MS. Interestingly, a companion paper in this issue shows that both mental health and musculoskeletal disorders were also the strongest contributors to lowering the health-related quality of life in people with MS in this same cohort. ${ }^{25}$ Mental health disorders (with a diagnosis of depression having the largest individual contribution) had the largest relative contribution to the severity of feelings of anxiety, feelings of depression, cognitive symptoms, sensory symptoms, fatigue and sexual dysfunction. Musculoskeletal 
disorders (with osteoporosis having the largest individual contribution) had the largest relative contribution to the severity of pain, walking difficulties, difficulty with balance, bladder problems, bowel problems and spasticity. Our findings align with the past literature in which mental health comorbidities, particularly a diagnosis of depression, were linked to higher severity of fatigue, disability and cognitive impairment. ${ }^{26}$ In one prospective study involving 106 people with relapsing-remitting MS, a diagnosis of depression was more common and more severe in PwMS who reported fatigue symptoms. ${ }^{27}$ Further, previous studies showed that a diagnosis of depression may exacerbate cognitive impairment in $\mathrm{PwMS}^{28,29}$ specifically for those with moderate to severe depression. ${ }^{30}$ Similarly, our results were consistent with other studies showing that musculoskeletal disorders contributes significantly to pain symptoms in PwMS. ${ }^{31,32}$ Further, Marrie and colleagues previously showed that PwMS were more likely to have osteoporosis due to low bone density which further contribute to the severity of bone fractures, immobility, balance problems and pain. ${ }^{33}$

Our findings indicate that it is important for clinicians to recognize the large impact of mental health and musculoskeletal disorders on the symptom severity in MS and to understand that the total number of comorbidities seem to have the biggest impact on feelings of anxiety, feelings of depression and pain. Understanding the interrelations between a patient's cumulative impact of comorbidities and MS symptom load is an important step in deciding on the optimal management strategies. Our study does not aim to attribute causation. While it is likely that comorbidities add to the symptom load of a person with MS, the converse may also happen, particularly where a symptom is an important determinant of the diagnosis of a comorbidity (i.e. higher feelings of depression and the diagnosis of depression). Irrespective of this, our findings support that early detection and routine screening, particularly of mental health disorders and musculoskeletal disorders, throughout the disease course could be a viable strategy to prevent and minimise the impact of these comorbidities on MS symptoms. It is also 
important for clinician's to be aware that medications for MS as well as comorbidities could have unwanted symptomatic side effects ${ }^{5,34}$. Comorbidity prevention and symptom reduction could be further assisted by empowering and assisting patients with a personalised approach around healthy lifestyle choices, such as following a healthy diet, maintaining adequate levels of physical activity and smoking cessation.

Strengths of the study are the inclusion of broad range of comorbidities as well as most common MS symptoms, which also allowed us to group comorbidities and identify the relative contribution of these comorbidity groups and individual comorbidities for each symptom severity. Although the AMSLS is a highly representative sample of the MS population, ${ }^{12}$ some selection bias may have occurred as not all participants answered the two surveys. When we compared participants, those who were included with those not included, there were only small differences in age and MS duration and no significant differences in education attainment and sex were observed. Although we were incapable of comparing all MS-specific characteristics between the included and excluded participants, our study sample shows similar distributions in sex and MS onset-types when compared with other MS cohort studies, ${ }^{35}$ making our results likely generalisable to the whole MS population. Using patient-reported data on comorbidities allowed us to include comorbidities that may be under-reported in medical records or excluded in clinical settings (e.g. allergies, migraine and musculoskeletal diseases). A limitation was that it might have caused some measurement error. To address this, we also asked whether the comorbidities were doctor-diagnosed and found that the results were similar irrespective of whether we used total or doctor-diagnosed comorbidities. 
In conclusion, a higher number of comorbidities was most strongly associated with higher severity of most MS symptoms, particularly for feelings of anxiety, feelings of depression and pain. Mental health and musculoskeletal disorders were the strongest contributors to the symptom severity load. A deeper understanding of the relationships between comorbidities and symptoms, as provided in this study, is beneficial for the management of PwMS by clinicians. Our work suggests that mental health and musculoskeletal comorbidities should be targeted for early detection, prevention and treatment to optimize the management of comorbidities in PwMS.

\section{Acknowledgement}

The authors would like to express their deepest gratitude for all the participants of the Australian Multiple Sclerosis Longitudinal Study for their continuous support and enthusiasm to respond to all surveys.

\section{Funding/Support}

This study was supported by Multiple Sclerosis Research Australia

\section{Conflict of interest}

The authors have no conflict of interest to disclose. 


\section{References:}

1. World Health Organization. Neurological Disorders: Public Health Challenges, https://www.who.int/mental_health/publications/neurological_disorders ph_challenges/en/ (2006, accessed 01 October 2019).

2. Gelfand JM. Chapter 12 - Multiple sclerosis: diagnosis, differential diagnosis, and clinical presentation. In: Goodin DS (ed) Handbook of Clinical Neurology. Elsevier, 2014, pp.269-290.

3. Ziemssen T. Symptom management in patients with multiple sclerosis. J Neurol Sci 2011; 311: S48-S52.

4. Zwibel HL and Smrtka J. Improving quality of life in multiple sclerosis: an unmet need. The American journal of managed care 2011; 17: S139-S145.

5. Tobin WO. Management of Multiple Sclerosis Symptoms and Comorbidities. Continuum (Minneap Minn) 2019; 25: 753-772

6. Marrie RA, Cohen J, Stuve O, et al. A systematic review of the incidence and prevalence of comorbidity in multiple sclerosis: Overview. Mult Scler J 2015; 21: 263-281. DOI: https://doi.org/10.1177/1352458514564491.

7. Marrie RA, Patten SB, Tremlett H, et al. Sex differences in comorbidity at diagnosis of multiple sclerosis: A population-based study. Neurology 2016; 86: 1279-1286.

8. Marrie RA and Horwitz RI. Emerging effects of comorbidities on multiple sclerosis. Lancet Neurol 2010; 9: 820-828. DOI: https://doi.org/10.1016/S1474-4422(10)70135-6.

9. Newland PK, Lorenz R, Budhathoki C, et al. The Presence of Symptoms With Comorbid Conditions in Individuals With Multiple Sclerosis (MS). Clin Nurs Res 2015; 25 : 532-548. DOI: https://doi.org/10.1177/1054773815592817.

10. Fiest KM, Fisk JD, Patten SB, et al. Comorbidity is associated with pain-related activity limitations in multiple sclerosis. Mult Scler Relat Disord 2015; 4: 470-476.

11. Fiest KM, Fisk JD, Patten SB, et al. Fatigue and Comorbidities in Multiple Sclerosis. Int J MS Care 2016; 18: 96-104.

12. Taylor BV, Palmer A, Simpson Jr S, et al. Assessing possible selection bias in a national voluntary MS longitudinal study in Australia. Mult Scler J 2013; 19: 1627-1631. DOI: https://doi.org/10.1177/1352458513481511.

13. Polman $\mathrm{CH}$, Reingold SC, Banwell B, et al. Diagnostic criteria for multiple sclerosis: 2010 revisions to the McDonald criteria. Ann Neurol 2011; 69: 292-302. DOI: https://doi.org/10.1002/ana.22366.

14. Kang JH, Chen $\mathrm{YH}$ and Lin HC. Comorbidities amongst patients with multiple sclerosis: a population-based controlled study. Eur J Neurol 2010; 17: 1215-1219. DOI: https://doi.org/10.1111/j.1468-1331.2010.02971.x. 
15. Marrie R, Horwitz R, Cutter G, et al. Comorbidity, socioeconomic status and multiple sclerosis. Mult Scler 2008; 14: 1091-1098. DOI: https://doi.org/10.1177/1352458508092263.

16. Zhang Y, Taylor BV, Simpson S, Jr., et al. Validation of 0-10 MS symptom scores in the Australian multiple sclerosis longitudinal study. Mult Scler Relat Disord 2020; 39.

17. Learmonth YC, Motl RW, Sandroff BM, et al. Validation of patient determined disease steps (PDDS) scale scores in persons with multiple sclerosis. BMC Neurology 2013; 13: 37 .

18. Hohol MJ, Orav EJ and Weiner HL. Disease steps in multiple sclerosis: a simple approach to evaluate disease progression. Neurology 1995; 45: 251-255.

19. Greenland S. Modeling and variable selection in epidemiologic analysis. Am J Public Health 1989; 79: 340-349.

20. Kamangar F. Confounding Variables in Epidemiologic Studies: Basics and Beyond. Arch Iran Med 2012; 15: 508-516.

21. Luchman J. DOMIN: Stata module to conduct dominance analysis, https://ideas.repec.org/c/boc/bocode/s457629.html (2013, accessed April 16 2018).

22. Azen R and Budescu D. The Dominance Analysis Approach for Comparing Predictors in Multiple Regression. Psychol Methods 2003; 8: 129-148.

23. Azen R and Traxel N. Using Dominance Analysis to Determine Predictor Importance in Logistic Regression. J Educ Behav Stat 2009; 34: 319-347.

24. Marrie RA. Comorbidities in Multiple Sclerosis: A Clinical Resource Guide, https://mscomorbidities.com/ (2018, accessed 17 March 2018).

25. Lo LMP, Taylor BV, Winzenberg T, Palmer AJ, Blizzard L, Ahmad H, Hussain MA, van der Mei I (2020) Estimating the relative contribution of comorbidities in predicting health-related quality of life of people with multiple sclerosis. J Neurol (Accepted)

26. Sascha Gill, B.Sc. „, Jonathan Santo, Ph.D. „, Mervin Blair, Ph.D. , C.Psych. ,, et al. Depressive Symptoms Are Associated With More Negative Functional Outcomes Than Anxiety Symptoms in Persons With Multiple Sclerosis. J Neuropsychiatry Clin Neurosci 2019; 31: 37-42.

27. Bakshi R, Shaikh ZA, Miletich RS, et al. Fatigue in multiple sclerosis and its relationship to depression and neurologic disability. Mult Scler J 2000; 6: 181-185.

28. Feinstein A. Mood disorders in multiple sclerosis and the effects on cognition. $J$ Neurol Sci 2006; 245: 63-66.

29. Morrow SA, Rosehart H and Pantazopoulos K. Anxiety and Depressive Symptoms Are Associated With Worse Performance on Objective Cognitive Tests in MS. $J$ Neuropsychiatry Clin Neurosci 2015; 28: 118-123.

30. Arnett PA, Barwick FH and Beeney JE. Depression in multiple sclerosis: Review and theoretical proposal. J Int Neuropsych Soc 2008; 14: 691-724. 
31. ShayestehAzar M, Kariminasab MH, Saravi MS, et al. A Survey of Severity and Distribution of Musculoskeletal Pain in Multiple Sclerosis Patients; a Cross-Sectional Study. Arch Bone Jt Surg 2015; 3: 114-118.

32. Dobson R, Ramagopalan S and Giovannoni G. Bone health and multiple sclerosis. Multiple Sclerosis Journal 2012; 18: 1522-1528. DOI: 10.1177/1352458512453362.

33. Marrie RA and Hanwell H. General Health Issues in Multiple Sclerosis: Comorbidities, Secondary Conditions, and Health Behaviors. Continuum (Minneap Minn) 2013; 19: 1046-1057.

34. Zhang $\mathrm{T}$, Tremlett $\mathrm{H}$, Leung $\mathrm{S}$, et al. Examining the effects of comorbidities on disease-modifying therapy use in multiple sclerosis. Neurology 2016; 86: 1287-1295. DOI: 10.1212/WNL.0000000000002543.

35. Degenhardt A, Ramagopalan SV, Scalfari A, et al. Clinical prognostic factors in multiple sclerosis: a natural history review. Nat Rev Neurol 2009; 5: 672-682. 
Table 1. Characteristics of the participants

\begin{tabular}{|c|c|}
\hline Characteristic & $\begin{array}{c}\text { Study sample } \\
(\mathrm{N}=1,223)\end{array}$ \\
\hline Number of people with MS with no comorbidity & $111(9.1)$ \\
\hline Number of people with MS with at least 1 comorbidity & $1,112(90.9)$ \\
\hline Age (years), mean (SD) & $56.1(11.2)$ \\
\hline MS duration since symptom onset (years), mean (SD) & $20.5(10.7)$ \\
\hline MS duration since diagnosis (years), mean (SD) & $15.2(8.9)$ \\
\hline \multicolumn{2}{|l|}{ Sex, n $(\%)$} \\
\hline Male & $260(21.3)$ \\
\hline Female & $963(78.7)$ \\
\hline \multicolumn{2}{|l|}{ Currently on Disease Modifying Therapy, n (\%) } \\
\hline Yes & $759(62.1)$ \\
\hline No & $464(37.9)$ \\
\hline \multicolumn{2}{|l|}{ Disease course at onset ${ }^{\mathrm{a}}, \mathrm{n}(\%)$} \\
\hline Relapse-onset Multiple Sclerosis ${ }^{b}$ & $862(87.8)$ \\
\hline Progressive-onset Multiple Sclerosis ${ }^{c}$ & $120(12.2)$ \\
\hline \multicolumn{2}{|l|}{ Body mass index $\left(\mathrm{kg} / \mathrm{m}^{2}\right), \mathrm{n}(\%)$} \\
\hline Normal $(B M I=18.5$ to 24.9$)$ & $503(42.5)$ \\
\hline Overweight (BMI $=25$ to 29.9) & $376(31.8)$ \\
\hline Obese $(B M I=30$ and over $)$ & $304(25.7)$ \\
\hline \multicolumn{2}{|l|}{ Patient Determined Disease Steps (PDDS) (0-8), n (\%) } \\
\hline No disability (PDDS score $=0)$ & $293(24.4)$ \\
\hline Mild disability $(P D D S$ score $=1-2)$ & $278(23.2)$ \\
\hline Moderate disability (PDDS score $=3-5)$ & $415(34.6)$ \\
\hline Severe disability (PDDS score $\geq 6)$ & $215(17.9)$ \\
\hline \multicolumn{2}{|l|}{ Education attainment, n (\%) } \\
\hline Primary and Secondary school & $356(29.3)$ \\
\hline Occupational certificate/diploma & $415(34.2)$ \\
\hline University bachelor's degree & $261(21.5)$ \\
\hline University postgraduate degree & $182(15.0)$ \\
\hline
\end{tabular}

${ }^{a}$ Excluded those who ticked "unsure" $(\mathrm{n}=139)$ and those who did not specify their MS onset type $(\mathrm{n}=102) ;{ }^{\mathrm{b}}$ Includes relapsing remitting multiple sclerosis and secondary progressive multiple sclerosis; ${ }^{\mathrm{c}}$ Includes primary progressive multiple sclerosis and progressive relapsing multiple sclerosis; ${ }^{\mathrm{d}}$ Body mass index (BMI) was calculated by dividing self-reported weight (in kilograms) by height ${ }^{2}$ (in centimetres). 


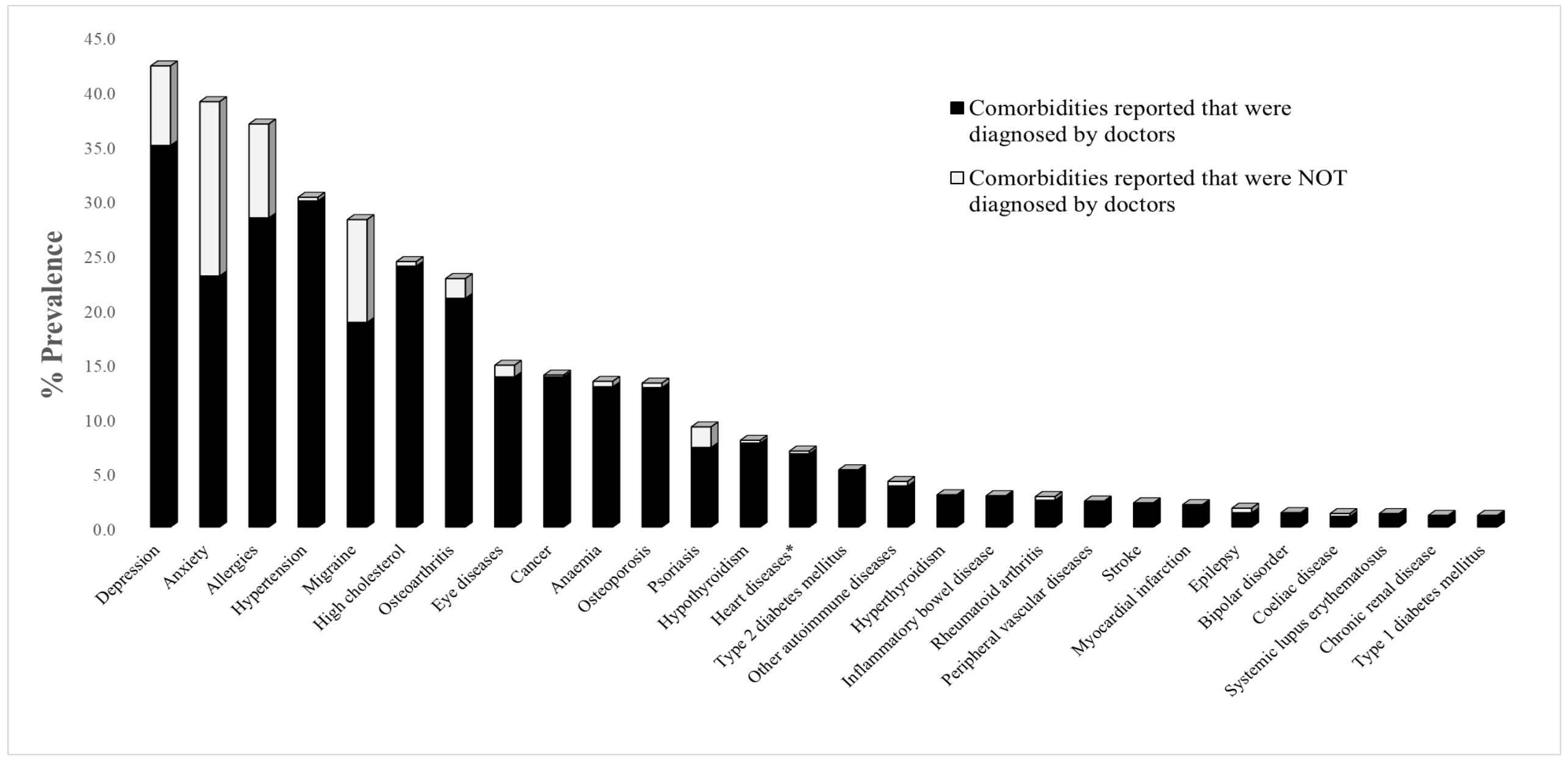

Figure 1. The prevalence of comorbidities in people with MS

*Heart diseases include angina, congestive heart failure and coronary artery disease. 


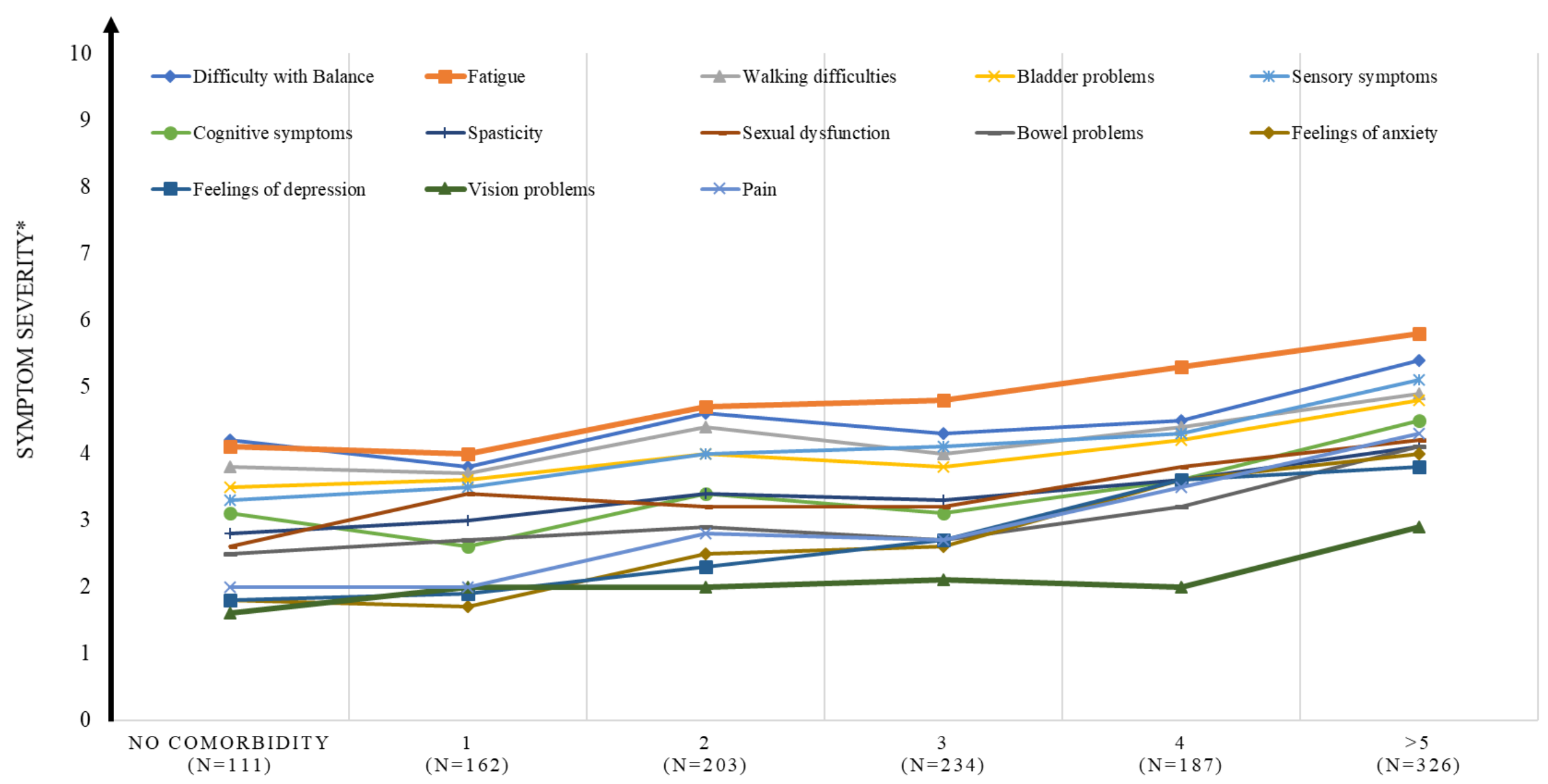

Figure 2. The mean severity of common symptoms of people with MS per total comorbidity increase*

*Each MS symptom severity was based from a 0 to 10 numeric rating scale wherein $0=$ least severe to $10=$ most severe. Total comorbidity refers to any comorbidity the participant reported having. 
Table 2. The adjusted ratios and average ratios of the means per total comorbidity ${ }^{\mathrm{a}}$ increase of people with MS

\begin{tabular}{|c|c|c|c|c|c|c|c|c|c|c|c|c|c|}
\hline No. & $\begin{array}{l}\text { Feelings of } \\
\text { anxiety }^{\mathrm{b}}\end{array}$ & $\begin{array}{l}\text { Feelings of } \\
\text { depression }^{\mathrm{b}}\end{array}$ & Pain $^{\mathrm{b}}$ & $\begin{array}{c}\text { Vision } \\
\text { problems }\end{array}$ & $\begin{array}{l}\text { Cognitive } \\
\text { symptoms }^{\mathrm{b}}\end{array}$ & $\begin{array}{c}\text { Sensory } \\
\text { symptoms }\end{array}$ & $\begin{array}{c}\text { Sexual } \\
\text { dysfunction }\end{array}$ & Spasticity $^{\mathrm{e}}$ & $\begin{array}{c}\text { Bowel } \\
\text { problems }\end{array}$ & Fatigue $^{\mathrm{c}}$ & $\begin{array}{l}\text { Difficulty } \\
\text { with } \\
\text { balance }^{\mathrm{f}}\end{array}$ & $\begin{array}{c}\text { Bladder } \\
\text { problems }\end{array}$ & $\begin{array}{c}\text { Walking } \\
\text { difficulty }\end{array}$ \\
\hline \multicolumn{14}{|c|}{ Adjusted ratio of means per comorbidity increase $e^{i}$} \\
\hline $\mathbf{0}$ & & & & & & & 1.00 (Ref) & & & & & & \\
\hline 1 & $\begin{array}{c}0.96 \\
(0.74-1.24)\end{array}$ & $\begin{array}{c}1.07 \\
(0.82-1.40)\end{array}$ & $\begin{array}{c}1.00 \\
(0.75-1.31)\end{array}$ & $\begin{array}{c}1.27 \\
(0.94-1.71)\end{array}$ & $\begin{array}{c}0.85 \\
(0.69-1.05)\end{array}$ & $\begin{array}{c}1.04 \\
(0.86-1.26)\end{array}$ & $\begin{array}{c}1.21 \\
(0.88-1.68)\end{array}$ & $\begin{array}{c}1.01 \\
(0.79-1.31)\end{array}$ & $\begin{array}{c}1.07 \\
(0.80-1.44)\end{array}$ & $\begin{array}{c}0.96 \\
(0.82-1.12)\end{array}$ & $\begin{array}{c}0.84 \\
(0.69-1.02)\end{array}$ & $\begin{array}{c}0.99 \\
(0.79-1.25)\end{array}$ & $\begin{array}{c}0.88 \\
(0.70-1.11)\end{array}$ \\
\hline 2 & $\begin{array}{c}1.42 \\
(1.12-1.80)\end{array}$ & $\begin{array}{c}1.31 \\
(1.01-1.67)\end{array}$ & $\begin{array}{c}1.35 \\
(1.04-1.75)\end{array}$ & $\begin{array}{c}1.30 \\
(0.98-1.73)\end{array}$ & $\begin{array}{c}1.11 \\
(0.92-1.35)\end{array}$ & $\begin{array}{c}1.16 \\
(0.97-1.39)\end{array}$ & $\begin{array}{c}1.10 \\
(0.80-1.49)\end{array}$ & $\begin{array}{c}1.16 \\
(0.92-1.48)\end{array}$ & $\begin{array}{c}1.16 \\
(0.88-1.54)\end{array}$ & $\begin{array}{c}1.10 \\
(0.95-1.28)\end{array}$ & $\begin{array}{c}1.01 \\
(0.85-1.21)\end{array}$ & $\begin{array}{c}1.10 \\
(0.88-1.37)\end{array}$ & $\begin{array}{c}1.09 \\
(0.88-1.35)\end{array}$ \\
\hline 3 & $\begin{array}{c}1.49 \\
(1.18-1.88)\end{array}$ & $\begin{array}{c}1.52 \\
(1.19-1.93)\end{array}$ & $\begin{array}{c}1.30 \\
(1.01-1.68)\end{array}$ & $\begin{array}{c}1.29 \\
(0.97-1.71)\end{array}$ & $\begin{array}{c}1.03 \\
(0.85-1.25)\end{array}$ & $\begin{array}{c}1.21 \\
(1.01-1.44)\end{array}$ & $\begin{array}{c}1.14 \\
(0.84-1.54)\end{array}$ & $\begin{array}{c}1.14 \\
(0.90-1.44)\end{array}$ & $\begin{array}{c}1.02 \\
(0.88-1.34)\end{array}$ & $\begin{array}{c}1.11 \\
(0.96-1.28)\end{array}$ & $\begin{array}{c}0.91 \\
(0.77-1.09)\end{array}$ & $\begin{array}{c}0.97 \\
(0.78-1.20)\end{array}$ & $\begin{array}{c}0.92 \\
(0.75-1.14)\end{array}$ \\
\hline 4 & $\begin{array}{c}2.05 \\
(1.62-2.60)\end{array}$ & $\begin{array}{c}2.00 \\
(1.56-2.56)\end{array}$ & $\begin{array}{c}1.71 \\
(1.31-2.22)\end{array}$ & $\begin{array}{c}1.24 \\
(0.93-1.66)\end{array}$ & $\begin{array}{c}1.20 \\
(0.99-1.46)\end{array}$ & $\begin{array}{c}1.21 \\
(1.01-1.46)\end{array}$ & $\begin{array}{c}1.31 \\
(0.96-1.80)\end{array}$ & $\begin{array}{c}1.21 \\
(0.95-1.54)\end{array}$ & $\begin{array}{c}1.21 \\
(0.91-1.61)\end{array}$ & $\begin{array}{c}1.23 \\
(1.06-1.42)\end{array}$ & $\begin{array}{c}0.95 \\
(0.80-1.14)\end{array}$ & $\begin{array}{c}1.09 \\
(0.87-1.37)\end{array}$ & $\begin{array}{c}0.98 \\
(0.79-1.22)\end{array}$ \\
\hline$\geq 5$ & $\begin{array}{c}2.28 \\
(1.83-2.84)\end{array}$ & $\begin{array}{c}2.28 \\
(1.73-2.74)\end{array}$ & $\begin{array}{c}2.04 \\
(1.60-2.60)\end{array}$ & $\begin{array}{c}1.83 \\
(1.40-2.39)\end{array}$ & $\begin{array}{c}1.50 \\
(1.25-1.79)\end{array}$ & $\begin{array}{c}1.47 \\
(1.24-1.74)\end{array}$ & $\begin{array}{c}1.47 \\
(1.10-1.97)\end{array}$ & $\begin{array}{c}1.40 \\
(1.12-1.76)\end{array}$ & $\begin{array}{c}1.51 \\
(1.16-1.96)\end{array}$ & $\begin{array}{c}1.34 \\
(1.17-1.54)\end{array}$ & $\begin{array}{c}1.10 \\
(0.93-1.31)\end{array}$ & $\begin{array}{c}1.21 \\
(0.99-1.50)\end{array}$ & $\begin{array}{c}1.13 \\
(0.92-1.38)\end{array}$ \\
\hline \multicolumn{14}{|c|}{ p-value for trend } \\
\hline
\end{tabular}

Adjusted average ratios of means per comorbidity increase ${ }^{i}$

\begin{tabular}{|c|c|c|c|c|c|c|c|c|c|c|c|c|}
\hline $\begin{array}{c}1.13 \\
(1.10-1.16)\end{array}$ & $\begin{array}{c}1.13 \\
(1.10-1.15)\end{array}$ & $\begin{array}{c}1.12 \\
(1.09-1.15)\end{array}$ & $\begin{array}{c}1.08 \\
(1.05-1.11)\end{array}$ & $\begin{array}{c}1.08 \\
(1.06-1.10)\end{array}$ & $\begin{array}{c}1.06 \\
(1.04-1.08)\end{array}$ & $\begin{array}{c}1.06 \\
(1.02-1.09)\end{array}$ & $\begin{array}{c}1.06 \\
(1.03-1.08)\end{array}$ & $\begin{array}{c}1.06 \\
(1.03-1.10)\end{array}$ & $\begin{array}{c}1.05 \\
(1.04-1.07)\end{array}$ & $\begin{array}{c}1.03 \\
(1.01-1.04)\end{array}$ & $\begin{array}{c}1.03 \\
(1.01-1.06)\end{array}$ & $\begin{array}{c}1.02 \\
(1.01-1.05)\end{array}$ \\
\hline
\end{tabular}

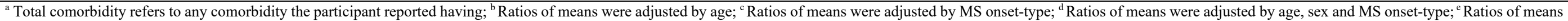

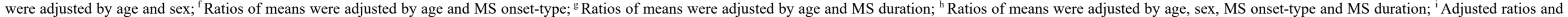
average ratios of mean in bold font indicate significance at $95 \%$ confidence interval (CI). 
Impact of comorbidities on MS symptoms

\section{Table 3. Relative contribution of comorbidity groups ${ }^{\mathrm{a}}$ for each MS symptom severity - results from general dominance analysis}

\begin{tabular}{|c|c|c|c|c|c|c|c|c|c|c|c|c|c|}
\hline $\begin{array}{c}\text { Common symptoms } \\
\text { in } \mathrm{MS}^{\mathrm{b}}\end{array}$ & $\begin{array}{l}\text { Feelings } \\
\text { of anxiety }\end{array}$ & $\begin{array}{l}\text { Depressive } \\
\text { symptoms }\end{array}$ & Pain & Fatigue & $\begin{array}{l}\text { Cognitive } \\
\text { symptoms }\end{array}$ & $\begin{array}{l}\text { Walking } \\
\text { difficulty }\end{array}$ & $\begin{array}{c}\text { Sensory } \\
\text { symptoms }\end{array}$ & $\begin{array}{c}\text { Difficulty } \\
\text { with } \\
\text { balance } \\
\end{array}$ & $\begin{array}{l}\text { Vision } \\
\text { problems }\end{array}$ & $\begin{array}{c}\text { Sexual } \\
\text { dysfunction }\end{array}$ & $\begin{array}{l}\text { Bowel } \\
\text { problems }\end{array}$ & $\begin{array}{l}\text { Bladder } \\
\text { problems }\end{array}$ & Spasticity \\
\hline $\begin{array}{l}\text { Total variance } \\
\text { explained by all } \\
\text { comorbidity groups } \\
\left(\% \mathrm{R}^{2}\right)\end{array}$ & 22.00 & 18.41 & 9.77 & 8.35 & 7.73 & 5.70 & 5.57 & 5.27 & 5.12 & 4.33 & 3.93 & 3.58 & 3.67 \\
\hline Comorbidity groups & \multicolumn{13}{|c|}{ Standardized general dominance weights ${ }^{j}$} \\
\hline Circulatory disorders ${ }^{\mathrm{c}}$ & $3.7(2)$ & 1.9 & 9.6 & 7.9 & 2.7 & 28.4 (2) & 7.3 & 27.7 (2) & 11.9 & 18.5 & 10.4 & $17.4(2)$ & 18.8 \\
\hline $\begin{array}{l}\text { Endocrine and } \\
\text { metabolic disorders }\end{array}$ & 1.4 & 1.6 & 7.5 & 8.4 & 5.2 & 4.4 & 2.3 & 9.4 & 5.1 & 3.6 & 13.8 & 3.3 & 1.4 \\
\hline Chronic renal disease & 0.1 & 0.1 & 1.4 & 0.1 & 1.0 & 0.9 & 2.6 & 1.0 & 0.3 & 0.3 & 0.2 & 1.8 & 0.3 \\
\hline $\begin{array}{l}\text { Musculoskeletal } \\
\text { disorders }^{\mathrm{e}}\end{array}$ & 3.6 & $5.9(2)$ & $29.5(\mathbf{1})$ & $15.8(2)$ & 3.1 & $41.1(\mathbf{1})$ & $15.6(2)$ & $34.6(1)$ & 18.6 & $18.6(2)$ & $34.4(1)$ & 32.5 (1) & $45.2(\mathbf{1})$ \\
\hline $\begin{array}{l}\text { Gastrointestinal } \\
\text { disorders }^{\mathrm{f}}\end{array}$ & 0.2 & 0.5 & 1.0 & 8.4 & 2.2 & 0.6 & 5.6 & 0.1 & 0.6 & 0.5 & 0.1 & 0.1 & 1.4 \\
\hline Psoriasis & 0.8 & 2.0 & 1.9 & 1.5 & 4.3 & 3.3 & 6.2 & 2.2 & 0.3 & 7.0 & 2.1 & 6.5 & 7.5 \\
\hline Anaemias & 0.3 & 0.5 & 0.3 & 0.8 & 0.8 & 3.7 & 8.1 & 1.7 & 0.7 & 3.5 & 2.6 & 0.3 & 0.8 \\
\hline $\begin{array}{l}\text { Nervous system } \\
\text { disorders }^{\mathrm{g}}\end{array}$ & 0.9 & 0.9 & 5.6 & 4.0 & $9.0(2)$ & 3.8 & 5.8 & 1.0 & 2.1 & 0.8 & 0.6 & 0.3 & 0.5 \\
\hline Cancer & 0.1 & 0.1 & 2.4 & 0.1 & 0.9 & 1.0 & 2.7 & 0.6 & 0.3 & 2.2 & 1.0 & 0.4 & 0.1 \\
\hline $\begin{array}{l}\text { Other autoimmune } \\
\text { disease }^{\mathrm{h}}\end{array}$ & 0.9 & 1.1 & 5.9 & 7.8 & 3.7 & 3.1 & 8.0 & 5.4 & 0.7 & 8.8 & 1.6 & 8.8 & 2.4 \\
\hline $\begin{array}{l}\text { Mental health } \\
\text { disorders }\end{array}$ & $87.3(1)$ & 84.9 (1) & $28.0(2)$ & $42.4(1)$ & $65.5(1)$ & 6.6 & 29.9 (1) & 11.8 & 27.7 (2) & $35.2(1)$ & 28.1 (2) & 16.7 & 20.4 (2) \\
\hline Eye diseases & 0.1 & 0.2 & 3.4 & 1.2 & 1.1 & 2.6 & 1.2 & 4.3 & 31.1 (1) & 0.6 & 3.1 & 9.0 & 1.0 \\
\hline
\end{tabular}

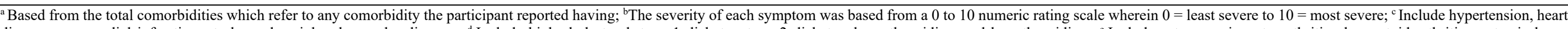

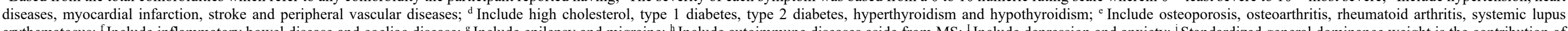

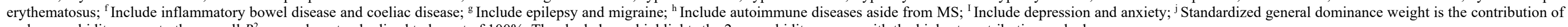
each comorbidity group to the overall $R^{2}$ normed or standardized to be out of $100 \%$. The shaded area highlights the 2 comorbidity groups with the highest contribution ranked. 
Table 4. Relative contribution of individual comorbidities ${ }^{\text {a }}$ for each MS symptom severity - results from general dominance analysis

\begin{tabular}{|c|c|c|c|c|c|c|c|c|c|c|c|c|c|}
\hline $\begin{array}{c}\text { Common } \\
\text { symptoms in } \mathrm{MS}^{\mathrm{b}}\end{array}$ & $\begin{array}{l}\text { Feelings } \\
\text { of anxiety }\end{array}$ & $\begin{array}{l}\text { Feelings of } \\
\text { depression }\end{array}$ & Pain & Fatigue & $\begin{array}{l}\text { Cognitive } \\
\text { symptoms }\end{array}$ & $\begin{array}{l}\text { Walking } \\
\text { difficulty }\end{array}$ & $\begin{array}{l}\text { Sensory } \\
\text { symptoms }\end{array}$ & $\begin{array}{l}\text { Difficulty } \\
\text { with } \\
\text { balance }\end{array}$ & $\begin{array}{c}\text { Vision } \\
\text { problems }\end{array}$ & $\begin{array}{c}\text { Sexual } \\
\text { dysfunction }\end{array}$ & $\begin{array}{l}\text { Bowel } \\
\text { problems }\end{array}$ & $\begin{array}{l}\text { Bladder } \\
\text { problems }\end{array}$ & Spasticity \\
\hline $\begin{array}{l}\text { Comorbidity } \\
\text { groups }\end{array}$ & \multicolumn{13}{|c|}{ Standardized general dominance weights ${ }^{\mathrm{c}}$} \\
\hline \multicolumn{14}{|c|}{ Circulatory disorders } \\
\hline Hypertension & 3.4 & - & - & - & - & $15.0(2)$ & - & 11.4 & - & - & - & 1.1 & - \\
\hline Heart diseases & 0.3 & - & - & - & - & 7.4 & - & $19.5(2)$ & - & - & - & $23.3(2)$ & - \\
\hline $\begin{array}{l}\text { Myocardial } \\
\text { infarction }\end{array}$ & 0.1 & - & - & - & - & 2.1 & - & 2.7 & - & - & - & 2.3 & - \\
\hline Stroke & 0.5 & - & - & - & - & 0.9 & - & 0.4 & - & - & - & 3.7 & - \\
\hline $\begin{array}{l}\text { Peripheral } \\
\text { vascular disease }\end{array}$ & 0.2 & - & - & - & - & 7.1 & - & 2.2 & - & - & - & 15.8 & - \\
\hline \multicolumn{14}{|c|}{ Musculoskeletal disorders } \\
\hline Osteoporosis & - & 2.0 & 17.0 & $28.8(2)$ & - & $59.0(1)$ & $25.8(2)$ & $50.3(1)$ & - & $28.7(2)$ & $52.1(1)$ & $42.2(\mathbf{1})$ & $58.0(1)$ \\
\hline Osteoarthritis & - & 2.4 & $26.8(2)$ & 7.5 & - & 5.0 & 9.0 & 5.4 & - & 13.2 & 9.3 & 8.9 & 5.7 \\
\hline $\begin{array}{l}\text { Rheumatoid } \\
\text { arthritis }\end{array}$ & - & 2.1 & 8.7 & 0.6 & - & 3.3 & 2.9 & 7.9 & - & 1.2 & 0.6 & 2.6 & 8.8 \\
\hline $\begin{array}{l}\text { Systemic lupus } \\
\text { erythematosus }\end{array}$ & - & 0.7 & 4.8 & 1.3 & - & 0.2 & 6.9 & 0.3 & - & 5.2 & 4.1 & 0.2 & 2.9 \\
\hline \multicolumn{14}{|c|}{ Nervous system disorders } \\
\hline Epilepsy & - & - & - & - & 6.4 & - & - & - & - & - & - & - & - \\
\hline Migraine & - & - & - & - & 6.7 & - & - & - & - & - & - & - & - \\
\hline \multicolumn{14}{|c|}{ Mental health disorders } \\
\hline Depression & 34.1 (2) & $76.0(1)$ & $28.3(\mathbf{1})$ & 49.4 (1) & $72.6(1)$ & - & 41.4 (1) & - & $30.1(2)$ & 43.5 (1) & $29.0(2)$ & - & $21.0(2)$ \\
\hline Anxiety & $61.4(\mathbf{1})$ & $16.7(2)$ & 14.5 & 12.3 & $14.3(2)$ & - & 14.1 & - & 17.5 & 8.2 & 4.9 & - & 3.7 \\
\hline Eye diseases & - & - & - & - & - & - & - & - & $52.4(1)$ & - & - & - & - \\
\hline
\end{tabular}


Supplementary Table 1. The unadjusted ratios and average ratios of the means per total comorbidity ${ }^{\mathrm{a}}$ increase of people with MS

\begin{tabular}{|c|c|c|c|c|c|c|c|c|c|c|c|c|c|}
\hline No. & $\begin{array}{c}\text { Feelings of } \\
\text { anxiety }\end{array}$ & $\begin{array}{l}\text { Feelings of } \\
\text { depression }\end{array}$ & Pain & $\begin{array}{c}\text { Vision } \\
\text { problems }\end{array}$ & $\begin{array}{l}\text { Cognitive } \\
\text { symptoms }\end{array}$ & $\begin{array}{c}\text { Bowel } \\
\text { problems }\end{array}$ & Fatigue & $\begin{array}{c}\text { Sensory } \\
\text { symptoms }\end{array}$ & $\begin{array}{c}\text { Sexual } \\
\text { dysfunction }\end{array}$ & $\begin{array}{c}\text { Bladder } \\
\text { problems }\end{array}$ & Spasticity & $\begin{array}{c}\text { Difficulty } \\
\text { with balance }\end{array}$ & $\begin{array}{l}\text { Walking } \\
\text { difficulty }\end{array}$ \\
\hline \multicolumn{14}{|c|}{ Unadjusted ratio of means per comorbidity increase ${ }^{b}$} \\
\hline $\mathbf{0}$ & & & & & & & 1.00 (Ref) & & & & & & \\
\hline 2 & $\begin{array}{c}1.41 \\
(1.11-1.79)\end{array}$ & $\begin{array}{c}1.30 \\
(1.01-1.67)\end{array}$ & $\begin{array}{c}1.36 \\
(1.05-1.76)\end{array}$ & $\begin{array}{c}1.30 \\
(0.98-1.73)\end{array}$ & $\begin{array}{c}1.11 \\
(0.91-1.35)\end{array}$ & $\begin{array}{c}1.17 \\
(0.88-1.54)\end{array}$ & $\begin{array}{c}1.13 \\
(0.98-1.30)\end{array}$ & $\begin{array}{c}1.20 \\
(1.01-1.43)\end{array}$ & $\begin{array}{c}1.26 \\
(0.93-1.71)\end{array}$ & $\begin{array}{c}1.13 \\
(0.90-1.42)\end{array}$ & $\begin{array}{c}1.21 \\
(0.95-1.54)\end{array}$ & $\begin{array}{c}1.14 \\
(0.92-1.41)\end{array}$ & $\begin{array}{c}1.20 \\
(1.01-1.43)\end{array}$ \\
\hline 3 & $\begin{array}{c}1.47 \\
(1.16-1.85)\end{array}$ & $\begin{array}{c}1.51 \\
(1.18-1.92)\end{array}$ & $\begin{array}{c}1.33 \\
(1.03-1.73)\end{array}$ & $\begin{array}{c}1.30 \\
(0.98-1.72)\end{array}$ & $\begin{array}{c}1.02 \\
(0.85-1.24)\end{array}$ & $\begin{array}{c}1.08 \\
(0.82-1.42)\end{array}$ & $\begin{array}{c}1.15 \\
(1.01-1.32)\end{array}$ & $\begin{array}{c}1.25 \\
(1.05-1.47)\end{array}$ & $\begin{array}{c}1.26 \\
(0.94-1.69)\end{array}$ & $\begin{array}{c}1.07 \\
(0.86-1.34)\end{array}$ & $\begin{array}{c}1.18 \\
(0.93-1.50)\end{array}$ & $\begin{array}{c}1.04 \\
(0.84-1.29)\end{array}$ & $\begin{array}{c}1.25 \\
(1.05-1.47)\end{array}$ \\
\hline 4 & $\begin{array}{c}2.02 \\
(1.60-2.56)\end{array}$ & $\begin{array}{c}1.98 \\
(1.55-2.54)\end{array}$ & $\begin{array}{c}1.75 \\
(1.35-2.27)\end{array}$ & $\begin{array}{c}1.25 \\
(0.94-1.68)\end{array}$ & $\begin{array}{c}1.19 \\
(0.98-1.45)\end{array}$ & $\begin{array}{c}1.27 \\
(0.96-1.69)\end{array}$ & $\begin{array}{c}1.29 \\
(1.12-1.48)\end{array}$ & $\begin{array}{c}1.30 \\
(1.10-1.55)\end{array}$ & $\begin{array}{c}1.49 \\
(1.10-2.01)\end{array}$ & $\begin{array}{c}1.19 \\
(0.94-1.50)\end{array}$ & $\begin{array}{c}1.27 \\
(0.99-1.62)\end{array}$ & $\begin{array}{c}1.14 \\
(0.91-1.42)\end{array}$ & $\begin{array}{c}1.30 \\
(1.10-1.55)\end{array}$ \\
\hline$\geq 5$ & $\begin{array}{c}2.21 \\
(1.78-2.76)\end{array}$ & $\begin{array}{c}2.14 \\
(1.70-2.69)\end{array}$ & $\begin{array}{c}2.11 \\
(1.66-2.69)\end{array}$ & $\begin{array}{c}1.86 \\
(1.43-2.42)\end{array}$ & $\begin{array}{c}1.47 \\
(1.23-1.76)\end{array}$ & $\begin{array}{c}1.61 \\
(1.24-2.09)\end{array}$ & $\begin{array}{c}1.42 \\
(1.24-1.61)\end{array}$ & $\begin{array}{c}1.53 \\
(1.31-1.80)\end{array}$ & $\begin{array}{c}1.65 \\
(1.25-2.18)\end{array}$ & $\begin{array}{c}1.36 \\
(1.10-1.68)\end{array}$ & $\begin{array}{c}1.46 \\
(1.16-1.82)\end{array}$ & $\begin{array}{c}1.27 \\
(1.04-1.55)\end{array}$ & $\begin{array}{c}1.53 \\
(1.31-1.80)\end{array}$ \\
\hline \multicolumn{14}{|c|}{ p-value for trend } \\
\hline & $\mathbf{p}<\mathbf{0 . 0 1}$ & $\mathbf{p}<\mathbf{0 . 0 1}$ & $\mathbf{p}<\mathbf{0 . 0 1}$ & $\mathbf{p}<0.01$ & $\mathbf{p}<\mathbf{0 . 0 1}$ & $\mathbf{p}<\mathbf{0 . 0 1}$ & $\mathbf{p}<\mathbf{0 . 0 1}$ & $\mathbf{p}<\mathbf{0 . 0 1}$ & $\mathbf{p}<\mathbf{0 . 0 1}$ & $\mathbf{p}<0.01$ & $\mathbf{p}<0.01$ & $\mathbf{p}<\mathbf{0 . 0 1}$ & $\mathbf{p}<\mathbf{0 . 0 1}$ \\
\hline \multicolumn{14}{|c|}{ 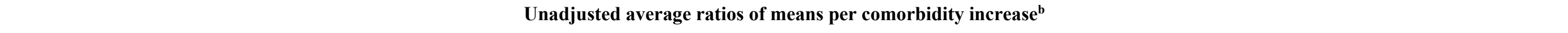 } \\
\hline & $\begin{array}{c}1.13 \\
(1.10-1.15)\end{array}$ & $\begin{array}{c}1.12 \\
(1.09-1.15)\end{array}$ & $\begin{array}{c}1.12 \\
(1.09-1.15)\end{array}$ & $\begin{array}{c}1.08 \\
(1.05-1.11)\end{array}$ & $\begin{array}{c}1.07 \\
(1.05-1.10)\end{array}$ & $\begin{array}{c}1.07 \\
(1.04-1.11)\end{array}$ & $\begin{array}{c}1.06 \\
(1.04-1.07)\end{array}$ & $\begin{array}{c}1.06 \\
(1.04-1.08)\end{array}$ & $\begin{array}{c}1.06 \\
(1.03-1.10)\end{array}$ & $\begin{array}{c}1.05 \\
(1.02-1.07)\end{array}$ & $\begin{array}{c}1.05 \\
(1.03-1.08)\end{array}$ & $\begin{array}{c}1.04 \\
(1.03-1.06)\end{array}$ & $\begin{array}{c}1.04 \\
(1.01-1.06)\end{array}$ \\
\hline
\end{tabular}




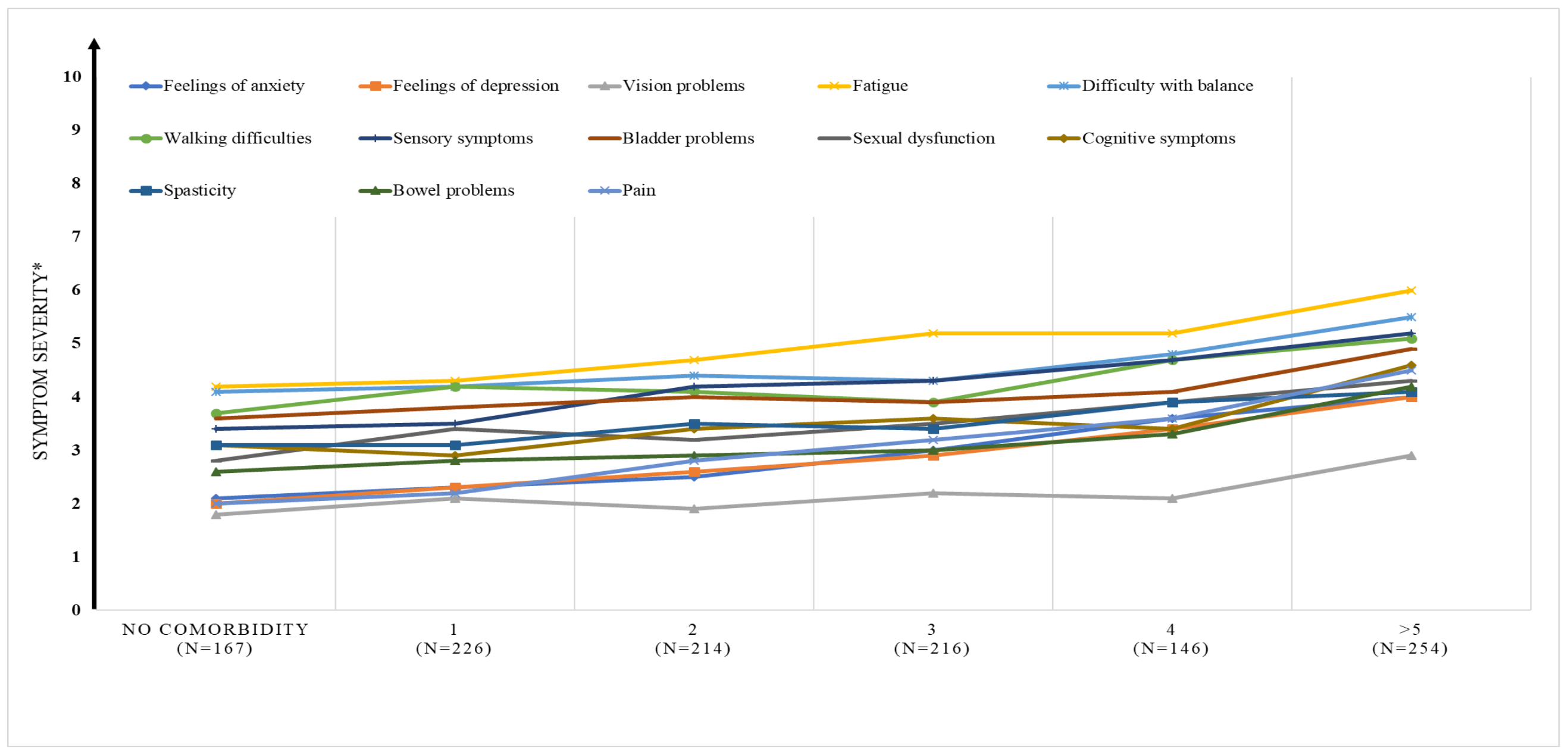

\section{Supplementary Figure 1. The mean severity of common symptoms of people with MS per doctor-diagnosed comorbidity increase}

* The severity of each symptom was based from a 0 to 10 numeric rating scale wherein $0=$ least severe to $10=$ most severe. Doctor-diagnosed comorbidity refers to any comorbidity the patient reported as diagnosed by a doctor. 
Supplementary Table 2. The unadjusted ratios and average ratios of the means per doctor-diagnosed comorbidity ${ }^{\mathrm{a}}$ increase of people with MS

\begin{tabular}{|c|c|c|c|c|c|c|c|c|c|c|c|c|c|}
\hline No. & Pain & $\begin{array}{l}\text { Feelings of } \\
\text { depression }\end{array}$ & $\begin{array}{c}\text { Feelings of } \\
\text { anxiety }\end{array}$ & $\begin{array}{c}\text { Bowel } \\
\text { problems }\end{array}$ & $\begin{array}{c}\text { Vision } \\
\text { problems }\end{array}$ & $\begin{array}{l}\text { Cognitive } \\
\text { symptoms }\end{array}$ & $\begin{array}{c}\text { Sensory } \\
\text { symptoms }\end{array}$ & Fatigue & $\begin{array}{c}\text { Sexual } \\
\text { dysfunction }\end{array}$ & $\begin{array}{l}\text { Bladder } \\
\text { problems }\end{array}$ & Spasticity & $\begin{array}{c}\text { Difficulty } \\
\text { with balance }\end{array}$ & $\begin{array}{l}\text { Walking } \\
\text { difficulty }\end{array}$ \\
\hline \multicolumn{14}{|c|}{ Unadjusted ratio of means per comorbidity increase ${ }^{b}$} \\
\hline $\mathbf{0}$ & & & & & & & $1.00(\operatorname{Ref})$ & & & & & & \\
\hline 1 & $\begin{array}{c}1.08 \\
(0.86-1.35)\end{array}$ & $\begin{array}{c}1.17 \\
(0.94-1.46)\end{array}$ & $\begin{array}{c}1.12 \\
(0.91-1.38)\end{array}$ & $\begin{array}{c}1.09 \\
(0.86-1.39)\end{array}$ & $\begin{array}{c}1.13 \\
(0.89-1.44)\end{array}$ & $\begin{array}{c}0.92 \\
(0.78-1.09)\end{array}$ & $\begin{array}{c}1.05 \\
(0.90-1.22)\end{array}$ & $\begin{array}{c}1.02 \\
(0.90-1.15)\end{array}$ & $\begin{array}{c}1.21 \\
(0.93-1.56)\end{array}$ & $\begin{array}{c}1.07 \\
(0.88-1.30)\end{array}$ & $\begin{array}{c}1.01 \\
(0.82-1.24)\end{array}$ & $\begin{array}{c}1.04 \\
(0.90-1.21)\end{array}$ & $\begin{array}{c}1.14 \\
(0.94(1.37)\end{array}$ \\
\hline 2 & $\begin{array}{c}1.38 \\
(1.10-1.72)\end{array}$ & $\begin{array}{c}1.30 \\
(1.05-1.61)\end{array}$ & $\begin{array}{c}1.22 \\
(1.00-1.51)\end{array}$ & $\begin{array}{c}1.12 \\
(0.88-1.43)\end{array}$ & $\begin{array}{c}1.08 \\
(0.84-1.37)\end{array}$ & $\begin{array}{c}1.09 \\
(0.92-1.29)\end{array}$ & $\begin{array}{c}1.25 \\
(1.08-1.45)\end{array}$ & $\begin{array}{c}1.10 \\
(0.97-1.24)\end{array}$ & $\begin{array}{c}1.15 \\
(0.88-1.49)\end{array}$ & $\begin{array}{c}1.13 \\
(0.93-1.39)\end{array}$ & $\begin{array}{c}1.15 \\
(0.93-1.41)\end{array}$ & $\begin{array}{c}1.09 \\
(0.94-1.27)\end{array}$ & $\begin{array}{c}1.10 \\
(0.91-1.33)\end{array}$ \\
\hline 4 & $\begin{array}{c}1.78 \\
(1.40-2.26)\end{array}$ & $\begin{array}{c}1.73 \\
(1.38-2.18)\end{array}$ & $\begin{array}{c}1.73 \\
(1.39-2.16)\end{array}$ & $\begin{array}{c}1.29 \\
(0.99-1.58)\end{array}$ & $\begin{array}{c}1.16 \\
(0.89-1.52)\end{array}$ & $\begin{array}{c}1.11 \\
(0.92-1.33)\end{array}$ & $\begin{array}{c}1.39 \\
(1.18-1.63)\end{array}$ & $\begin{array}{c}1.23 \\
(1.08-1.40)\end{array}$ & $\begin{array}{c}1.40 \\
(1.06-1.85)\end{array}$ & $\begin{array}{c}1.14 \\
(0.92-1.42)\end{array}$ & $\begin{array}{c}1.29 \\
(1.02-1.62)\end{array}$ & $\begin{array}{c}1.18 \\
(1.01-1.40)\end{array}$ & $\begin{array}{c}1.28 \\
(1.04-1.57)\end{array}$ \\
\hline$\geq 5$ & $\begin{array}{c}2.21 \\
(1.79-2.74)\end{array}$ & $\begin{array}{c}2.04 \\
(1.66-2.50)\end{array}$ & $\begin{array}{c}1.93 \\
(1.59-2.34)\end{array}$ & $\begin{array}{c}1.61 \\
(1.27-2.03)\end{array}$ & $\begin{array}{c}1.59 \\
(1.26-2.01)\end{array}$ & $\begin{array}{c}1.47 \\
(1.25-1.73)\end{array}$ & $\begin{array}{c}1.54 \\
(1.34-1.77)\end{array}$ & $\begin{array}{c}1.41 \\
(1.26-1.59)\end{array}$ & $\begin{array}{c}1.55 \\
(1.21-1.99)\end{array}$ & $\begin{array}{c}1.38 \\
(1.14-1.68)\end{array}$ & $\begin{array}{c}1.34(1.10- \\
1.64)\end{array}$ & $\begin{array}{c}1.35 \\
(1.17-1.56)\end{array}$ & $\begin{array}{c}1.37 \\
(1.14-1.64)\end{array}$ \\
\hline \multicolumn{14}{|c|}{ p-value for trend } \\
\hline & $\mathbf{p}<\mathbf{0 . 0 1}$ & $\mathbf{p}<\mathbf{0 . 0 1}$ & $\mathbf{p}<\mathbf{0 . 0 1}$ & $\mathbf{p}<\mathbf{0 . 0 1}$ & $\mathbf{p}<\mathbf{0 . 0 1}$ & $\mathbf{p}<\mathbf{0 . 0 1}$ & $\mathbf{p}<\mathbf{0 . 0 1}$ & $\mathbf{p}<\mathbf{0 . 0 1}$ & $\mathbf{p}<\mathbf{0 . 0 1}$ & $\mathbf{p}<\mathbf{0 . 0 1}$ & $\mathbf{p}<0.01$ & $\mathbf{p}<\mathbf{0 . 0 1}$ & $\mathbf{p}<\mathbf{0 . 0 1}$ \\
\hline \multicolumn{14}{|c|}{ Unadjusted average ratios of means per comorbidity increase $e^{b}$} \\
\hline
\end{tabular}




\section{Supplementary Table 3. The adjusted ratios and average ratios of the means per doctor-diagnosed comorbidity ${ }^{\mathrm{a}}$ increase of people with MS}

\begin{tabular}{|c|c|c|c|c|c|c|c|c|c|c|c|c|c|}
\hline No. & Pain $^{b}$ & $\begin{array}{l}\text { Feelings of } \\
\text { depression }^{\mathrm{b}}\end{array}$ & $\begin{array}{l}\text { Feelings of } \\
\text { anxiety }^{\mathrm{b}}\end{array}$ & $\begin{array}{c}\text { Vision } \\
\text { problems }^{b}\end{array}$ & $\begin{array}{l}\text { Cognitive } \\
\text { symptoms }^{\text {b }}\end{array}$ & $\begin{array}{c}\text { Sensory } \\
\text { symptoms }^{\mathrm{c}}\end{array}$ & $\begin{array}{c}\text { Bowel } \\
\text { problems }^{\text {b }}\end{array}$ & $\begin{array}{c}\text { Sexual } \\
\text { dysnfunction }^{\mathrm{d}}\end{array}$ & Spasticity & Fatigue $^{\mathrm{c}}$ & $\begin{array}{c}\text { Difficulty } \\
\text { with } \\
\text { balance }^{\mathrm{f}}\end{array}$ & $\begin{array}{c}\text { Bladder } \\
\text { problems }^{\mathrm{g}}\end{array}$ & $\begin{array}{l}\text { Walking } \\
\text { difficulty }^{\mathrm{h}}\end{array}$ \\
\hline \multicolumn{14}{|c|}{ Adjusted ratio of means per comorbidity increase ${ }^{i}$} \\
\hline $\mathbf{0}$ & & & & & & & .00 (Ref) & & & & & & \\
\hline 1 & $\begin{array}{c}1.07 \\
(0.85-1.34)\end{array}$ & $\begin{array}{c}1.17 \\
(0.95-1.46)\end{array}$ & $\begin{array}{c}1.13 \\
(0.92-1.39)\end{array}$ & $\begin{array}{c}1.13 \\
(0.89-1.44)\end{array}$ & $\begin{array}{c}0.92 \\
(0.78-1.10)\end{array}$ & $\begin{array}{c}1.03 \\
(0.88-1.20)\end{array}$ & $\begin{array}{c}1.09 \\
(0.85-1.38)\end{array}$ & $\begin{array}{c}1.17 \\
(0.90-1.52)\end{array}$ & $\begin{array}{c}0.98 \\
(0.80-1.21)\end{array}$ & $\begin{array}{c}1.00 \\
(0.88-1.14)\end{array}$ & $\begin{array}{c}0.99 \\
(0.85-1.16)\end{array}$ & $\begin{array}{c}1.03 \\
(0.85-1.26)\end{array}$ & $\begin{array}{c}1.11 \\
(0.92-1.33)\end{array}$ \\
\hline 2 & $\begin{array}{c}1.36 \\
(1.09-1.71)\end{array}$ & $\begin{array}{c}1.31 \\
(1.06-1.63)\end{array}$ & $\begin{array}{c}1.24 \\
(1.01-1.52)\end{array}$ & $\begin{array}{c}1.07 \\
(0.84-1.37)\end{array}$ & $\begin{array}{c}1.09 \\
(0.92-1.30)\end{array}$ & $\begin{array}{c}1.23 \\
(1.05-1.44)\end{array}$ & $\begin{array}{c}1.10 \\
(0.86-1.41)\end{array}$ & $\begin{array}{c}1.05 \\
(0.81-1.38)\end{array}$ & $\begin{array}{c}1.12 \\
(0.91-1.38)\end{array}$ & $\begin{array}{c}1.07 \\
(0.94-1.21)\end{array}$ & $\begin{array}{c}1.05 \\
(0.90-1.23)\end{array}$ & $\begin{array}{c}1.09 \\
(0.90-1.33)\end{array}$ & $\begin{array}{c}1.08 \\
(0.89-1.30)\end{array}$ \\
\hline 3 & $\begin{array}{c}1.54 \\
(1.23-1.93)\end{array}$ & $\begin{array}{c}1.48 \\
(1.20-1.83)\end{array}$ & $\begin{array}{c}1.46 \\
(1.19-1.79)\end{array}$ & $\begin{array}{c}1.19 \\
(0.93-1.52)\end{array}$ & $\begin{array}{c}1.18 \\
(1.00-1.40)\end{array}$ & $\begin{array}{c}1.25 \\
(1.07-1.46)\end{array}$ & $\begin{array}{c}1.12 \\
(0.88-1.42)\end{array}$ & $\begin{array}{c}1.21 \\
(0.93-1.58)\end{array}$ & $\begin{array}{c}1.09 \\
(0.89-1.34)\end{array}$ & $\begin{array}{c}1.19 \\
(1.05-1.34)\end{array}$ & $\begin{array}{c}0.96 \\
(0.82-1.13)\end{array}$ & $\begin{array}{c}1.01 \\
(0.82-1.22)\end{array}$ & $\begin{array}{c}1.01 \\
(0.83-1.22)\end{array}$ \\
\hline 4 & $\begin{array}{c}1.74 \\
(1.37-2.22)\end{array}$ & $\begin{array}{c}1.75 \\
(1.39-2.21)\end{array}$ & $\begin{array}{c}1.77 \\
(1.42-2.21)\end{array}$ & $\begin{array}{c}1.15 \\
(0.88-1.51)\end{array}$ & $\begin{array}{c}1.12 \\
(0.93-1.35)\end{array}$ & $\begin{array}{c}1.29 \\
(1.09-1.53)\end{array}$ & $\begin{array}{c}1.22 \\
(0.94-1.59)\end{array}$ & $\begin{array}{c}1.24 \\
(0.93-1.67)\end{array}$ & $\begin{array}{c}1.25 \\
(1.00-1.57)\end{array}$ & $\begin{array}{c}1.18 \\
(1.02-1.35)\end{array}$ & $\begin{array}{c}1.05 \\
(0.88-1.25)\end{array}$ & $\begin{array}{c}1.02 \\
(0.82-1.27)\end{array}$ & $\begin{array}{c}1.14 \\
(0.93-1.41)\end{array}$ \\
\hline$\geq 5$ & $\begin{array}{c}2.13 \\
(1.72-2.65)\end{array}$ & $\begin{array}{c}2.10 \\
(1.71-2.58)\end{array}$ & $\begin{array}{c}2.02 \\
(1.65-2.46)\end{array}$ & $\begin{array}{c}1.56 \\
(1.23-1.98)\end{array}$ & $\begin{array}{c}1.51 \\
(1.28-1.78)\end{array}$ & $\begin{array}{c}1.49 \\
(1.28-1.73)\end{array}$ & $\begin{array}{c}1.49 \\
(1.18-1.88)\end{array}$ & $\begin{array}{c}1.42 \\
(1.09-1.84)\end{array}$ & $\begin{array}{c}1.31 \\
(1.07-1.60)\end{array}$ & $\begin{array}{c}1.34 \\
(1.19-1.52)\end{array}$ & $\begin{array}{c}1.18 \\
(1.01-1.38)\end{array}$ & $\begin{array}{c}1.22 \\
(1.01-1.48)\end{array}$ & $\begin{array}{c}1.24(1.03- \\
1.49)\end{array}$ \\
\hline \multicolumn{14}{|c|}{ p-value for trend } \\
\hline & $\mathbf{p}<0.01$ & $\mathrm{p}<0.01$ & $\mathrm{p}<0.01$ & $\mathbf{p}<0.01$ & $\mathrm{p}<0.01$ & $\mathrm{p}<0.01$ & $\mathrm{P}<0.01$ & $P=0.01$ & $\mathrm{p}<0.01$ & $\mathrm{p}<0.01$ & $p=0.02$ & $\mathrm{p}=0.07$ & $p=0.04$ \\
\hline
\end{tabular}

Adjusted average ratios of means per comorbidity increase ${ }^{i}$

\begin{tabular}{|c|c|c|c|c|c|c|c|c|c|c|c|c|}
\hline $\begin{array}{c}1.12 \\
(1.09-1.16)\end{array}$ & $\begin{array}{c}1.12 \\
(1.09-1.14)\end{array}$ & $\begin{array}{c}1.11 \\
(1.08-1.14)\end{array}$ & $\begin{array}{c}1.07 \\
(1.04-1.10)\end{array}$ & $\begin{array}{c}1.07 \\
(1.05-1.09)\end{array}$ & $\begin{array}{c}1.06 \\
(1.04-1.08)\end{array}$ & $\begin{array}{c}1.06 \\
(1.03-1.09)\end{array}$ & $\begin{array}{c}1.05 \\
(1.02-1.09)\end{array}$ & $\begin{array}{c}1.05 \\
(1.02-1.08)\end{array}$ & $\begin{array}{c}1.05 \\
(1.04-1.07)\end{array}$ & $\begin{array}{c}1.03 \\
(1.01-1.05)\end{array}$ & $\begin{array}{c}1.03 \\
(1.01-1.05)\end{array}$ & $\begin{array}{c}1.03 \\
(1.01-1.05)\end{array}$ \\
\hline
\end{tabular}

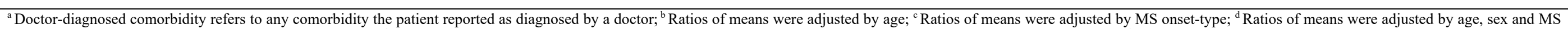

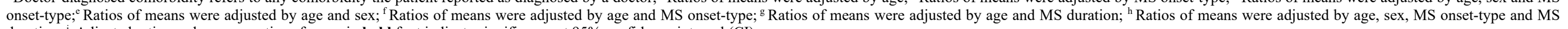
duration; ${ }^{i}$ Adjusted ratios and average ratios of mean in bold font indicate significance at $95 \%$ confidence interval (CI) 
Supplementary Table 4. Relative contribution of doctor-diagnosed comorbidity ${ }^{\text {a }}$ groups for each MS symptom severity- results from general dominance analysis

\begin{tabular}{|c|c|c|c|c|c|c|c|c|c|c|c|c|c|}
\hline $\begin{array}{c}\text { Common symptoms } \\
\text { in } \mathrm{MS}^{\mathrm{b}}\end{array}$ & $\begin{array}{l}\text { Feelings } \\
\text { of } \\
\text { anxiety } \\
\end{array}$ & $\begin{array}{l}\text { Feelings of } \\
\text { depression }\end{array}$ & Pain & Fatigue & $\begin{array}{l}\text { Cognitive } \\
\text { symptoms }\end{array}$ & $\begin{array}{l}\text { Sensory } \\
\text { symptoms }\end{array}$ & $\begin{array}{l}\text { Walking } \\
\text { difficulty }\end{array}$ & $\begin{array}{l}\text { Difficulty } \\
\text { with } \\
\text { balance } \\
\end{array}$ & $\begin{array}{l}\text { Vision } \\
\text { problems }\end{array}$ & $\begin{array}{c}\text { Bowel } \\
\text { problems }\end{array}$ & $\begin{array}{c}\text { Sexual } \\
\text { dysfunction }\end{array}$ & $\begin{array}{l}\text { Bladder } \\
\text { problems }\end{array}$ & Spasticity \\
\hline $\begin{array}{l}\text { Total variance } \\
\text { explained by all } \\
\text { comorbidity groups } \\
\left(\% \mathrm{R}^{2}\right)\end{array}$ & 15.02 & 14.33 & 10.69 & 7.76 & 6.21 & 5.78 & 5.26 & 5.03 & 4.15 & 3.86 & 3.67 & 3.48 & 3.24 \\
\hline Comorbidity groups & \multicolumn{13}{|c|}{ Standardized general dominance weights ${ }^{\mathrm{j}}$} \\
\hline $\begin{array}{l}\text { Circulatory } \\
\text { disorders }\end{array}$ & $4.2(2)$ & 1.8 & 9.0 & 8.9 & 2.8 & 7.0 & $28.9(2)$ & $28.7(2)$ & 13.2 & 10.1 & 18.7 & $18.5(2)$ & $21.2(2)$ \\
\hline $\begin{array}{l}\text { Endocrine and } \\
\text { metabolic disorders }\end{array}$ & 2.2 & 1.9 & 6.9 & 8.7 & 5.5 & 2.9 & 4.6 & 9.7 & 6.8 & 12.1 & 4.1 & 2.6 & 1.7 \\
\hline Chronic renal disease & 0.1 & 0.1 & 1.4 & 0.2 & 0.3 & 2.2 & 1.1 & 1.2 & 0.4 & 0.3 & 0.6 & 2.0 & 0.3 \\
\hline $\begin{array}{l}\text { Musculoskeletal } \\
\text { disorders }^{\mathrm{e}}\end{array}$ & 4.1 & $6.8(2)$ & 24.7 (2) & $17.8(2)$ & 5.2 & $14.2(2)$ & 41.8 (1) & 35.4 (1) & $22.3(2)$ & $37.5(1)$ & $20.8(2)$ & 31.9 (1) & 48.9 (1) \\
\hline $\begin{array}{l}\text { Gastrointestinal } \\
\text { disorders }^{\mathrm{f}}\end{array}$ & 0.2 & 0.5 & 0.7 & 8.9 & 1.7 & 4.2 & 0.6 & 0.4 & 0.7 & 0.6 & 0.1 & 0.2 & 0.8 \\
\hline Psoriasis & 1.5 & 3.3 & 1.4 & 2.4 & 6.1 & 6.0 & 2.5 & 1.2 & 1.0 & 0.4 & 5.7 & 5.8 & 3.4 \\
\hline Anaemia & 0.5 & 0.8 & 0.3 & 0.7 & 1.4 & 6.5 & 5.6 & 2.7 & 0.7 & 1.2 & 6.1 & 0.2 & 1.4 \\
\hline $\begin{array}{l}\text { Nervous system } \\
\text { disorders }^{\mathrm{g}}\end{array}$ & 1.2 & 1.3 & 11.4 & 7.7 & $13.9(2)$ & 13.6 & 0.3 & 2.4 & 4.8 & 2.2 & 3.3 & 2.6 & 2.4 \\
\hline Allergies & 3.3 & 2.1 & 8.8 & 1.9 & 2.7 & 5.9 & 1.6 & 0.6 & 0.4 & 2.2 & 0.7 & 0.5 & 0.7 \\
\hline Cancer & 0.1 & 0.1 & 1.9 & 0.1 & 1.3 & 2.6 & 0.8 & 0.5 & 0.6 & 0.8 & 2.0 & 0.3 & 0.1 \\
\hline $\begin{array}{l}\text { Other autoimmune } \\
\text { disease }^{\mathrm{h}}\end{array}$ & 0.8 & 0.4 & 3.8 & 5.4 & 1.5 & 5.2 & 2.3 & 0.7 & 0.3 & 0.8 & 6.0 & 5.7 & 3.0 \\
\hline $\begin{array}{l}\text { Mental health } \\
\text { disorders }\end{array}$ & 81.5 (1) & 80.8 (1) & 27.3 (1) & 36.5 (1) & $56.8(1)$ & 27.7 (1) & 5.1 & 6.9 & 10.1 & $26.3(2)$ & $31.6(\mathbf{1})$ & 15.2 & 14.3 \\
\hline Eye diseases & 0.3 & 0.3 & 2.7 & 1.0 & 1.0 & 2.0 & 4.8 & 6.8 & 38.76 (1) & 5.7 & 0.6 & 14.6 & 1.9 \\
\hline
\end{tabular}

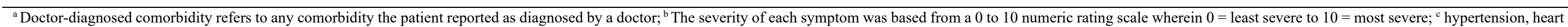

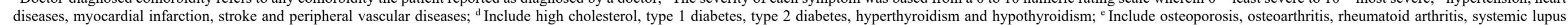

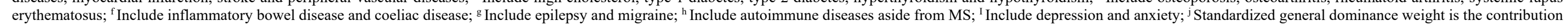
of each comorbidity group to the overall $R^{2}$ normed or standardized to be out of $100 \%$. The shaded area highlights the 2 comorbidity groups with the highest contribution ranked. 
Impact of comorbidities on MS symptoms

Supplementary Table 5. Relative contribution of individua doctor-diagnosed comorbidities ${ }^{a}$ for each MS symptom severity - results from general dominance analysis

\begin{tabular}{|c|c|c|c|c|c|c|c|c|c|c|c|c|c|}
\hline $\begin{array}{c}\text { Common } \\
\text { symptoms in } \mathrm{MS}^{\mathrm{b}}\end{array}$ & $\begin{array}{l}\text { Feelings } \\
\text { of anxiety }\end{array}$ & $\begin{array}{l}\text { Feelings of } \\
\text { depression }\end{array}$ & Pain & Fatigue & $\begin{array}{l}\text { Cognitive } \\
\text { symptoms }\end{array}$ & $\begin{array}{l}\text { Sensory } \\
\text { symptoms }\end{array}$ & $\begin{array}{l}\text { Walking } \\
\text { difficulty }\end{array}$ & $\begin{array}{c}\text { Difficulty } \\
\text { with } \\
\text { balance }\end{array}$ & $\begin{array}{l}\text { Vision } \\
\text { problems }\end{array}$ & $\begin{array}{l}\text { Bowel } \\
\text { problems }\end{array}$ & $\begin{array}{c}\text { Sexual } \\
\text { dysfunction }\end{array}$ & $\begin{array}{l}\text { Bladder } \\
\text { problems }\end{array}$ & Spasticity \\
\hline $\begin{array}{l}\text { Comorbidity } \\
\text { groups }\end{array}$ & & & & & & Standardize & general do & inance weig & & & & & \\
\hline \multicolumn{14}{|c|}{ Circulatory disorders } \\
\hline Hypertension & 3.5 & - & - & - & - & - & $12.5(2)$ & 12.7 & - & - & - & 1.0 & 4.9 \\
\hline Heart diseases & 0.5 & - & - & - & - & - & 11.2 & $20.1(2)$ & - & - & - & $27.3(2)$ & $12.5(2)$ \\
\hline $\begin{array}{l}\text { Myocardial } \\
\text { infarction }\end{array}$ & 0.2 & - & - & - & - & - & 2.2 & 3.2 & - & - & - & 3.5 & 1.1 \\
\hline Stroke & 0.5 & - & - & - & - & - & 0.7 & 0.7 & - & - & - & 2.3 & 7.0 \\
\hline $\begin{array}{l}\text { Peripheral } \\
\text { vascular disease }\end{array}$ & 0.2 & - & - & - & - & - & 7.5 & 3.0 & - & - & - & 15.9 & 6.1 \\
\hline \multicolumn{14}{|c|}{ Musculoskeletal disorders } \\
\hline Osteoporosis & - & 2.5 & 14.4 & $27.3(2)$ & - & $21.2(2)$ & $56.5(1)$ & 45.2 (1) & 9.8 & $53.7(1)$ & $26.3(2)$ & 38.2 (1) & $52.2(1)$ \\
\hline Osteoarthritis & - & 2.6 & $25.0(2)$ & 8.1 & - & 10.0 & 5.9 & 7.2 & $16.6(2)$ & 10.2 & 16.7 & 7.8 & 5.3 \\
\hline $\begin{array}{l}\text { Rheumatoid } \\
\text { arthritis }\end{array}$ & - & 3.0 & 9.3 & 2.0 & - & 4.5 & 3.4 & 7.7 & 9.7 & 0.3 & 1.4 & 3.8 & 8.5 \\
\hline $\begin{array}{l}\text { Systemic lupus } \\
\text { erythematosus }\end{array}$ & - & 0.6 & 3.9 & 1.6 & - & 5.7 & 0.2 & 0.2 & 3.8 & 3.2 & 4.7 & 0.3 & 2.5 \\
\hline \multicolumn{14}{|c|}{ Nervous system disorders } \\
\hline Epilepsy & - & - & - & - & 4.1 & - & - & - & - & - & - & - & - \\
\hline Migraine & - & - & - & - & $11.0(2)$ & - & - & - & - & - & - & - & - \\
\hline \multicolumn{14}{|c|}{ Mental health disorders } \\
\hline Depression & $43.8(2)$ & 77.8 (1) & 32.1 (1) & 45.5 (1) & $78.6(1)$ & 45.9 (1) & - & - & - & 28.7 (2) & 46.9 (1) & - & - \\
\hline Anxiety & $51.4(1)$ & $13.7(2)$ & 15.4 & 15.4 & 6.4 & 13.1 & - & - & - & 3.9 & 4.0 & - & - \\
\hline Eye diseases & - & - & - & - & - & - & - & - & $60.1(1)$ & - & - & - & - \\
\hline
\end{tabular}

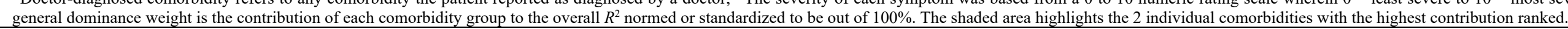

